\title{
Representing the Falklands Conflict in Words and Pictures
}

La représentation du conflit des Malouines par le texte et par l'image

\section{Michael Parsons}

\section{(2) OpenEdition \\ 12 Journals}

Electronic version

URL: http://journals.openedition.org/rfcb/6147

ISSN: 2429-4373

Publisher

CRECIB - Centre de recherche et d'études en civilisation britannique

Printed version

Date of publication: 1 June 2010

ISSN: 0248-9015

\section{Electronic reference}

Michael Parsons, "Representing the Falklands Conflict in Words and Pictures", Revue Française de Civilisation Britannique [Online], XV-4 | 2010, Online since 01 June 2010, connection on 07 January 2021. URL: http://journals.openedition.org/rfcb/6147

This text was automatically generated on 7 January 2021.

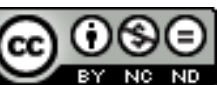

Revue française de civilisation britannique est mis à disposition selon les termes de la licence Creative Commons Attribution - Pas d'Utilisation Commerciale - Pas de Modification 4.0 International. 


\title{
Representing the Falklands Conflict in Words and Pictures
}

\author{
La représentation du conflit des Malouines par le texte et par l'image
}

\author{
Michael Parsons
}

1 The Falklands conflict if 1982 was an event that generated intense interest, although very few people were able to witness anything of what went on in the South Atlantic. The distance, the vastness of the oceans and seas in which the naval engagements took place, the remote nature of the terrain and the fact that many of the most significant infantry battles took place at night, combined with the fact that there was little real enthusiasm on the part of the military authorities for encouraging a flow of news from the task force and from the islands, meant that hard facts were hard to come by. Facts alone are of course not sufficient to understand what is really happening, and as in any military campaign the strategies and tactics adopted by the leaders of both sides remained secret. This did not stop commentators from trying to make sense of events, but the interpretations that this guessing game led to were often very wide of the mark. So, even obtaining information about events as they unfolded in a way that made sense of otherwise unconnected incidents was a difficult task.

2 Representation of developments in the South Atlantic was further hampered by the difficulty experienced in obtaining pictures, even still photographs, that said anything really significant to a general public which had become used to the idea that modern news-gathering technology would provide a steady stream of television reports. The absence of television footage or graphic photographs to illustrate events as they occurred fuelled a sense of frustration that the public was being deprived of information, even when the bare facts were announced by the authorities.

3 The conflict therefore generated much public debate about news coverage. It is difficult in this context to underestimate the extent to which people feel they have not been 'informed' about what is going on unless they have pictures, especially television pictures, to make it all feel 'real'. 
The conflict also offers an interesting debate about how events should be 'represented': how intense moments can or should be captured by artists or indeed by any one of the protagonists or witnesses of the events and the resulting pictures hung in art galleries, officers' messes and other places where this form of memory is usually put on display. There was disagreement about what it was that should be recorded and what artistic conventions were appropriate. The Falklands conflict was recorded by the first official war artist to join British forces since the Second World War. Expectations of what a war artist was supposed to produce were frustrated, a situation which was to be repeated in later conflicts, notably the war in Iraq. Alternative visions were offered by artists apparently feeling that the official artist had not used a uniquely privileged opportunity as they would have wished.

There were other very different contemporary and subsequent representations of the Falklands war offered by servicemen who had been involved and who used art to express their pain and frustration, or by cartoonists who expressed their disquiet about the political background to the conflict, though they have remained relatively unremarked.

\section{The meaning of 'representation'}

$6 \quad$ It is perhaps useful at this stage to look briefly at what is meant by 'representation' in order to see how the problems involved in representing the Falklands conflict can shed light on the concept itself. I am excluding the political meaning of representation from this discussion and focussing on the issue of representation as the process of making something present in the mind of a listener or reader. In this sense it is possible to consider how the events of the South Atlantic in 1982 might have been misrepresented or under-represented. The question is one of the creation of meaning, of making sense of 'events', of 'constructing discourse'. ${ }^{1}$ Representation is about interpretation and about identifying what is significant and what is not in what can be a confusing mass of facts. This is always problematic, but it is especially so in the context of the inevitable 'fog of war'.

7 The Shorter Oxford Dictionary provides the following definition for the meaning of 'representation' which I am primarily concerned with in discussing the way historical events are mediated and represented:

The action of placing a fact, etc., before another or others by means of discourse; a statement of account ... The action of presenting to the mind or imagination ... The act or process by which the mind forms an image or concept

and for the verb 'to represent':

To represent something is to describe or depict it, to call it up in the mind by description or portrayal or imagination; to place a likeness of it before us in our mind or in the senses.

8 Representing the Falklands conflict therefore involves a mental process of constructing, or reconstructing, the 'reality' of what happened, making sense of it and conjuring it up 'realistically' in the minds of listeners, viewers and readers. Framed in these terms there must be some doubt as to whether any attempt to represent a military conflict such as the Falklands War can ever succeed. Nobody who has not been in a battle (and I certainly have not and hope never to be) can, I suppose, really have the experience 'represented' to them. Even participants will probably have experienced 
a necessarily limited subset of the total event. And yet representation is important for both the general public and for the servicemen and others who were caught up in the events. The general public wants - needs - to know what is being done in its name, especially in time of war. It wants the facts laid before it, and it wants to know what they mean. Participants clearly experience a need to capture memories of events and attempt to make sense of them in their own terms. In both cases the process necessarily involves interpretation and selection.

In this article I propose to look beyond the well-documented issue of how the media were 'handled', how censorship was imposed and how access to news and communications facilities was restricted during the Falklands War and see first how facts alone do not constitute a 'representation' of what happened, unless they are assembled into a meaningful interpretation of events. This is especially difficult when widely-held frameworks for interpretation fail to account for the specific nature of the events concerned and lead to inaccurate representations or complete misrepresentations.

10 I then propose to look at the issue of photographic and artistic representations of the war, and the different and even conflicting goals photographers, newspapers and artists have pursued in their attempts to represent the Falklands in pictorial form. I will suggest that in many cases what is shown is more a re-hash of previous conflicts, moulding the current events to fit pre-existing narratives of what a war is supposed to be like, than a genuine attempt to portray or depict what it was really like. I will further suggest that representations which do not fit into those pre-established patterns are likely to be given much less prominence than those that do.

11 Finally I will very briefly comment on the way that heroes are part of the narrative of any conflict, and that in many cases the acts of heroism they accomplished recall those of earlier conflicts.

\section{The facts do not speak for themselves}

12 The first of the definitions of representation reproduced above refers to 'placing a fact before another or other by means of discourse'. In the Falklands war even this degré zéro de la représentation presented major challenges. Access to the theatre of war was strictly controlled by the two belligerents, forms of vetting or censorship were applied on both sides and the ability to transmit any kind of material was seriously constrained by the shortage of transmission facilities throughout most of the conflict. This was most obviously a handicap for the television journalists. For (probably) mainly technical reasons it was never possible to transmit television footage via satellite. Television material therefore had to be taken back physically, and a substantial part of the journey, at least as far as Ascension Island, had to be made by ship. Image transfer time was therefore measured not in megabytes per second but in knots.

This frustrated the expectations which had been raised among war correspondents in the aftermath of the Vietnam War, during which journalists had had unprecedented and possibly unique - access to the battlefield. To all intents and purposes they had had unlimited access to the scene of the action, and produced dramatic reports, photographs and film. However, they did not yet have access to the Electronic News Gathering (ENG) technology which was developed during the latter part of the 1970s 
and film had to be flown back to the United States. By the early 1980s, satellite transmission technology had made substantial advances and it was thought that pictures of any 'modern' war would be made very rapidly available. There was an expectation that 'news' (which was increasingly being taken to mean video pictures) would be coming out in a regular and rapid stream.

Most comment about news coverage of the Falklands war concentrated on this issue. Relations between the media and the authorities became so strained and criticism so vocal that a parliamentary enquiry was announced even before the conflict had come to an end and the enquiry itself was held shortly afterwards. It gives a fascinating insight into the expectations of the media, the goals of the politicians and the mindset of the military - and the almost inevitable conflict of interests between them. And it is not only the politicians and the military that come in for justified criticism in the report; the weaknesses, jealousies and sometimes disturbing egotism of some of the journalists emerge clearly. The most serious complaint made by the 'print' journalists was that their copy was sometimes held up for a few hours and therefore missed the deadlines for the following day's paper. In the meantime the ultra-bland but largely accurate (if rather terse) briefings given by the Ministry of Defence in London meant that much of the news obtained by the journalists on the spot was rendered useless because it did not reach their offices in time. Almost perversely, the messages were so bland, especially those read by the MoD spokesman Ian McDonald, that many listeners assumed that the news was being massaged or at least sanitised, even when it was not.

All of this raises serious questions about what news is and about what the role of the journalist on the spot should be. And even if the 'simple facts', if there is such a thing, could be established, did they 'make sense' without a clear understanding of the logic behind them? The Falklands war provides perhaps a little-noticed example of a phenomenon which became much more obvious with later wars, when 24-hour television provided a flow of pictures, and yet the audience only got a very partial view of what was really going on. In the end, the Gulf War stressed the importance of analysis and interpretation, and demonstrated that merely showing 'events' happening (whatever might be meant by an 'event' or indeed by 'happening') was not enough and indeed could arguably be presented as a regressive development, with the meaning of what was happening being overwhelmed in a flood of unprocessed 'facts' and pictures. The importance of seeing individual events within the right analytical framework is admirably illustrated by one of the military engagements of the Falklands War which remains controversial even today: the sinking of the Argentine cruiser General Belgrano.

\section{Coverage of the Belgrano incident : the right facts, but the wrong analytical framework}

Britain's response to the Argentine invasion of April 21982 was to send a task force, while at the same time seeking the support of the United Nations, rapidly obtaining a Security Council resolution (502) which required all armed forces to be withdrawn and invited the two countries involved to initiate negotiations. Britain's partners within the European Economic Community, particularly France, gave their support, though some, such as Ireland and Spain, were reluctant, and it was not clear whether that support, expressed essentially through their willingness to impose various forms of economic 
embargo, would be sustained if Britain were to pursue the military option. Britain also received clear messages of support and some practical assistance from the countries of the Commonwealth. The United States, on the other hand, was embarrassed at the prospect of a conflict between a major European ally and a country which represented in US eyes an important bastion against Communism in Latin America and a major asset in the campaign in El Salvador.

The newspapers, both in Britain and abroad, tended to interpret the development of the military option as a gradual imposition of pressure designed to back up diplomacy. More generally, most media comment saw the unfolding of events in the light of the prevailing doctrine for low intensity conflicts, that of gradual escalation. ${ }^{2}$ This doctrine was part of the theory of 'flexible response' which emerged in the 1950s to replace the former predominant 'philosophy', associated notably with John Foster Dulles, of 'massive reprisals'. It allowed for military pressure to be applied gradually, in carefully calculated steps.

The danger of this 'doctrine' is that it implies that in small-scale crises such as the Falklands affair military 'pressure' can always be 'applied' in carefully controlled doses according to precise political objectives. A crisis is by definition unpredictable. More significantly, the controlled 'application' of 'pressure', while it sounds fine in theory, may not be so easily managed in practice. In the Falklands War, neither side had a level of military superiority such that it could ensure that every military initiative would be at all times consistent with the political objectives at that precise time.

Nonetheless, that was how it seemed to many observers as the month of April progressed. British warships had very visibly left port on April 5; on April 12 Britain had declared a 'Maritime Exclusion Zone' (MEZ) 200 miles around the islands; on April 23 Britain had warned that any vessel or aircraft deemed to be a threat to the task force would be dealt with accordingly, and two days later, on April 25, the island of South Georgia had been recaptured. Meanwhile, Argentina had rejected the terms drawn up by Alexander Haig, the Secretary of State, and so the United States had officially announced support for Britain on April 30. That same day, Britain announced a 'Total Exclusion Area' (TEZ) 200 miles around the archipelago. Some people even claimed that the task force had been ordered to sail deliberately slowly to allow ample time for diplomacy, though this is largely unfounded. ${ }^{3}$ Britain, the media commented, was progressively 'piling it on', and no doubt they explicitly or implicitly saw the campaign as running on course according to the doctrine of gradual escalation and proportionality. For example, a leading article in The Times commented, '[t]he policy of gradually increasing the military pressure on the Argentine forces step by step has shown that strength was being applied with judgement'. ${ }^{4}$

20 The media saw further gradual escalation when, in the early hours of May 1, a single Vulcan bomber, which had left Ascension Island accompanied by a number of tanker aircraft for in-flight refuelling, dropped a line of heavy bombs across the airfield at Port Stanley. At dawn, a number of Harrier 'jump jets' took off from the aircraft carrier HMS Hermes and attacked targets on the Falklands, especially the airfield. A detachment of warships also bombarded the airfield at Stanley.

21 All of this activity was more or less accurately reported; it was widely interpreted as a stepping up of the military pressure. It therefore came as something of a shock to the world when the sinking of the Belgrano was announced. Public opinion was struck by what seemed to many to have been an unwarranted and sudden escalation of the 
military pressure. The gradual application and flexible response which so many people had identified in British military initiatives seemed to have been suddenly and inexplicably abandoned. Casualties had been thus far kept low, but 368 Argentine sailors died after the attack on the Belgrano. That shock was further compounded when, two days later, a British warship, HMS Sheffield, was struck by an Exocet missile, killing twelve seamen, and emphasising the vulnerability of warships on both sides to weapons which had not been used before in a major naval encounter. Not unreasonably, the attack on HMS Sheffield was considered as a reprisal for the loss of the Belgrano.

This was the reading of events - all of which were reported at the time, reasonably accurately and without undue delay, with the hugely important exception of the course pursued by the Belgrano when it was sunk - and it is the interpretation which seems to have survived in most people's memories. However, the 'gradual escalation' interpretation is largely inaccurate. The events as reported take on a quite different meaning when they are set against the background of military strategy.

The military authorities had to plan right from the start for a military conclusion to the crisis, whether or not they believed it could be solved by diplomacy. After all, one cannot commit forces in support of diplomacy, and, if the diplomacy fails, simply turn around and say the forces were never really intended to be used. It is nothing more than the simple rules of calling someone's bluff. So while the military option could be cancelled at any moment, it had to start right from the beginning on the basis that it would not.

The Chiefs of Staff had no illusions about the difficulties they faced. Indeed some of them were not too happy about sending the task force in the first place. Such anxieties as there were were fully borne out by events. The major difficulties were the distance at which the operation would have to be conducted and the weather conditions. The Falkland Islands were 8,000 miles from Britain, yet only 400 miles from Argentina. So while Britain's military strength was superior to Argentina's, the relative distances went some considerable way towards cancelling out that advantage. The weather was also a major headache, and the timetable was extremely tight. The Navy advised that it would be impossible to keep ships operational for more than six months in the conditions of the South Atlantic, and that after three months the efficiency of the fleet would begin to decline. Moreover, the South Atlantic winter would make many of the operations involved in establishing a beachhead practically impossible, as well as making conditions generally debilitating. That left a 'window of opportunity' of less than three months. The armed forces' logistics experts got to work and calculated that it was just possible, but that there was no time to spare.

In any case, an opposed landing was an unappealing prospect at the best of times, as Dieppe, Normandy and the island-hopping landings in the Pacific had amply demonstrated during the Second World War. Without air supremacy and dominance of the sea it would be a seriously unattractive proposal. Britain's carrier strength was limited and it did not yet have early-warning radar aircraft in the area, both of which meant that its ability to achieve air supremacy could not be taken for granted. The task force certainly had little room for manoeuvre: if one carrier had been sunk, then the task force would probably have had to abandon the operation.

Perhaps even more significantly, this was a limited conflict, and it needed international support to succeed, and that placed major political constraints on the military. There was no question of authorising direct attacks against Argentina. Consequently, while 
Britain's aircraft could be attacked on their 'bases', the aircraft carriers, Argentina's could not. Similarly, while the best part of the Royal Navy was with the task force and susceptible to Argentine attack, the Argentine Navy could remain in port, only 400 miles from the war zone, without risk.

The commander of the task force, Admiral 'Sandy' Woodward, knew that no amphibious landing was possible unless Argentina's navy had been overcome. During a landing several elements of any naval force are particularly vulnerable: the infantry involved in the landing, and also the navy, whose vessels have to come in close and often remain immobile for relatively long periods of time while troops transfer to landing vessels.

He also knew that the Argentine navy was fully aware of its own weaknesses, and would only come out to battle if it believed the British forces were especially vulnerable for one reason or another. Woodward was uncomfortably aware of the vulnerability of the task force even without having to support an amphibious landing. He knew that the Argentines knew the position of the force, but he did not know where most of the Argentine navy was. His brief, however, was to prepare the way for a landing, and he knew he could waste no time doing it.

The only way he saw of achieving this was to draw the Argentine navy out by pretending to launch a full-scale landing straight into the capital Port Stanley. He believed that the Argentine Navy's familiarity with United States strategy would lead them to assume that such a landing would be made the American way, going straight for the main target and relying on superior fire power to protect the landing force. Looked at in this light, the events of April and May led up logically to this outcome.

So the actions taken by the task force commander were not simply the carefullymanaged application of force in gradually increasing quantity in pursuit of a clearlyidentified objective, assumed to be the essentially diplomatic goal of Argentine withdrawal and subsequent negotiations over ultimate sovereignty, but rather a fullscale naval engagement. We now know that the order of events, and indeed the events themselves, could have been quite different. It is believed that an Argentine submarine fired a torpedo at a British ship on May 1, but failed. The following day, the Argentine aircraft carrier Veinticinco de Mayo attempted to launch an airborne bombing attack against British ships. That also failed, simply because the wind was not quite strong enough to allow the heavily laden bombers to take off. The Argentine air force attempted an Exocet attack that same day, using the same tactics, equipment and pilots as on May 4 when HMS Sheffield was hit. A fault in the in-flight refuelling system meant that the attack had to be abandoned. Argentine planes did attack the ships which were bombarding Port Stanley, but the bombs missed. So the first ships to have been damaged in this battle could well have been British. Equally, we know that the Rules of Engagement at the end of April allowed for attacks against the Argentine aircraft carrier. But the submarine which had been shadowing the carrier lost contact with it. Otherwise, it might well have been sunk before the Belgrano.

It would be tedious to pursue any further this ultimately pointless exercise in counterfactual history. It does however, I believe, emphasise the fact that the events of the opening days of May cannot be explained in terms of a controlled gradual escalation. Interpreting the facts which were reported (or, to be more precise, were announced by the British government) as unjustifiable escalation, in the case of the Belgrano, and as retaliation, in the case of the Sheffield, is very much wide of the mark and gives a 
completely misleading picture of what was really going on. The Belgrano was sunk as part of a British policy of forcing the Argentine navy permanently out of the seas around the Falklands, so that the Navy could fulfil its mission to prepare the way for a landing, and the Sheffield was hit during an Argentine attempt to strike a decisive blow against the Royal Navy while it was, or so the Argentine forces had been manoeuvred into believing, at its most vulnerable. The order in which these two events occurred was to a large extent fortuitous.

The facts, then, cannot speak for themselves. The events can only be accurately represented if the framework in which they occur is also understood. In the particular example of the events of May 1 to May 4 1982, it is perfectly clear that the framework could not have been made public. The commander of the Task Force could hardly have set out to spin a web of deception (his own words) and then tell the media. And there is nothing unusual in war about the use of surprise and disinformation. It is salutary to remember this at a time when providers of news still claim that events can be brought to you directly by means of new technologies. It is partly true, but only to a very limited extent. Speed is no substitute for depth.

So merely relating 'facts' - insofar as they are available - without the explanatory narrative is misleading, if not downright wrong. The facts without the background can be seriously misconstrued and therefore misrepresented.

\section{The pictorial record}

One of the remarkable features of war reporting in the South Atlantic was the dearth of visual images, both video and photographs. What video footage there was only reached television screens between 10 and 23 days after it was filmed. The result was that by the time the television pictures were shown the war itself had moved on to a new phase and this sharply diminished the impact of the pictures which eventually did reach people's homes. ${ }^{5}$

Even still pictures were relatively few and far between and significantly delayed. In all 202 photographs were sent back during the conflict. A substantial proportion of those taken in the early days of the campaign show ships sailing southwards over the vast ocean. Apart from a few obvious technological features the pictures could have come directly from a Second World War collection or from a film such as The Cruel Sea. One of the best photographs of that period shows the military matériel - helicopters and other equipment - being prepared under the main deck of the aircraft-carrier HMS Hermes. The picture is remarkable not because it is an accurate representation of the hectic work being done to organise the hastily-assembled stores on board the ships of the task force but because it is a strangely beautiful picture suggesting a certain serene order. In this respect the picture could remind one of debates over war art during the Second World War in which some artists' work was criticised for seeking to impose a sense of order on events which were in fact essentially chaotic.

The first picture to be transmitted from land facilities - with remarkable speed - was a picture of a British soldier drinking a mug of tea which has obviously been given to him by liberated Falklanders at Goose Green who smile gratefully at the camera. The picture fits into a convention of war pictures which has a long pedigree. The photographer Tom Smith was apparently surprised - and even irritated - that of all the pictures he had taken on the Falklands this was the one which the newspapers were most keen to 
publish. There was also some criticism on the part of the newspapers that this picture was clearly given pride of place by the authorities and sent back to London with almost indecent haste. Asked about this during the enquiry, the Ministry said, rather disingenuously, that they had thought the newspapers would be keen to print it. Since it was practically the first shot out of the Falklands after the landing this was indeed the case, but it would have been so for almost any picture. The authorities were quite clearly seeking to project an image of what the armed forces was doing on the islands with which they were comfortable.

Other photographs which were later to assume an almost iconic status were less popular with the authorities, the most evocative example of which was Martin Cleaver's photograph of the explosion of HMS Antelope. Transmission of the picture was undoubtedly delayed, but it became an instant success with the newspapers. It has been suggested that this is at least in part because it meets a Robert Capa-like quest for a photograph of the moment of death - when the ship exploded the two bomb disposal experts who were trying to defuse the bomb were killed instantly. The photograph also fitted nicely within a tradition of naval art: the moment of spectacular destruction as part of a naval engagement (even if in this case the final explosion took place well after the attack which had placed the bomb deep inside the ship).

Pictures of the fighting for the hills overlooking Stanley (and particularly pictures of soldiers anxiously installing a saline drip for one of their seriously injured comrades) echoed images from previous conflicts. So did some of the photographs taken of the end of the hostilities (particularly the photographs showing piles of Argentine weapons taken from prisoners of war).

It seems fairly evident that pictures were taken or published not so much to represent the 'reality' of the Falklands conflict as to locate the war within a narrative which would be familiar to readers and encouraged by the authorities.

\section{What is a war artist supposed to represent?}

The Imperial War Museum commissioned Linda Kitson to be the official war artist accompanying the task force. A director at the museum had been impressed by an exhibition of her sketches he had just seen and felt she could grasp quickly the essence of events. Perhaps it is significant in this respect that there was immense uncertainty at the outset as to whether the task force would in the end be anything more than a show of strength to support negotiations. In short, the official war artist might have ended up without a war to represent.

41 Linda Kitson's drawings attracted quite a lot of criticism, some of which focused on the apparently 'unfinished' nature of her work. Apparently one disappointed officer remarked, no doubt sarcastically, that 'they might be better when she has time to colour them in'. ${ }^{6}$ According to Tom Wilcox, in a chapter in Framing the Falklands War entitled, ' 'We are All Falklanders Now': Art, War and National Identity', 'the press was evidently unimpressed by Kitson's work, though picking up on her own description of her drawings as "squiggles".'

There was a fundamental reason why Kitson's work did not attract unanimous support. It failed to conform to pre-established views of what war art should be about: 
A 'running record' of the war (as Kitson described it) which avoided both evident acts of heroism or [sic] images of blood and guts was considered to be 'drastically uninformative in terms both of emotional mood and technical content'. Expecting either condemnation or sensationalism, the engagement with the everyday life of the Task Force which Kitson's drawings reveal was largely left out of discussion in the press. ${ }^{8}$ who certainly appears to have felt like this (though he never says so explicitly) is David

At Goose Green, I had to make a decision about what aspects of war I should record. My brief was to record the sights that might be recognised as common experiences. I decided then that the horrifying sight of parts of human bodies, a helmet with a head still in it - pictorially relevant though they were - were not part of my brief; neither were the war graves, which were recorded on news film and in photographs. I still question that decision. Would it have been a stronger, cautionary record if I had used such tactics? ${ }^{9}$

Many of her pictures show groups of men in more or less chaotic environments, poring over maps, sending signals, servicing equipment, relaxing, drilling, training or lying in hospital beds. Ms Kitson travelled in the QE2 and some of her pictures reflect the often incongruous juxtaposition of heavy weapons and the perfume shop or the signals squadron and intelligence service and the hairdressing salon of the hastily-converted luxury liner. Other sketches show helicopters and landing craft. Once she had landed on the Falklands she drew pictures of helicopters ferrying supplies to and fro, the makeshift living quarters, the POW camps, command posts, men in trenches and the aftermath of battles with the tangled wreckage of Argentine planes, helicopters evacuating casualties and the spectacular fire on the Sir Galahad after the air attack which killed fifty-one men and wounded hundreds more. She drew sketches of military vehicles of all kinds and of the guns, ammunition and equipment collected from the Argentine forces after the cease fire. The most common theme is men working hectically, often at tables with maps or typewriters or communications equipment, or men relaxing or generally milling around, talking, working, resting. There are however no pictures of battles taking place: but then she was not present or able to see much fighting; and the kind of warfare which characterised the Falklands campaign did not lend itself to real-time sketches.

The disappointment - or more or less muted criticism - generated by Linda Kitson's drawings can be explained by the fact that by commenting on the relatively commonplace they did not correspond to the narrative of war that her critics wanted to see brought to life in the work of the official war artist.

Some 'unofficial war artists' were clearly disappointed that they were not selected to sail with the fleet and seem to suggest that they would have done a better job of it. One 
Cobb, an accomplished painter with a long history of work for and with the Navy as a sailor and then an artist. He had only just opened an exhibition of war art when the conflict broke out. He was very keen to record as much as he could of the naval preparations and the departure of the ships. Although his view is laid out in very carefully measured terms it does not seem unreasonable to infer from the way he describes his role in his book The Making of a War Artist that he was disappointed: after recalling how he had spent his life painting pictures of naval engagements, and had indeed served in the Royal Navy, while Linda Kitson, despite her family connections, clearly had not, he writes, 'though I was carrying out the duty of one, I had no appointment as an official War Artist (Linda Kitson was to have that honour)'. ${ }^{10}$

David Cobb travelled to the Falklands after the end of the conflict with the help of the RAF, Army and Navy and given a number of commissions to paint pictures of some of the major events of the war, particularly by the Royal Navy. For Cobb art can do much more than photography, by setting events in their context:

... events in war do not oblige photographers, television teams or anyone else; the more distant the subject the less effective the photography seemed to become. To me, at least, it snuffed out past and future, space behind and movement beyond the border of the picture. The ships were set in concrete waves, with spray stuck in mid-air; the tramping soldier's boot would never reach the ground; the mists around the mountains were fixed in place. ${ }^{11}$

Before he left for the Falklands he spent a lot of time with servicemen who had taken part in the actions he wanted to recreate on paper or canvas and tried to sketch out with them their perception of what had happened, modifiying or redrawing the sketches in response to their perceptions. It becomes clear from reading his account of the way he worked to produce his paintings of the campaign that he was involved in recreation as much as representation. What he painted had to 'fit' with a view, based apparently on prior knowledge and experience, combined with extensive interviews with participants and visits to the locations themselves. Some places could be disappointing in this respect. For example he writes that 'the exact site and function of Ascension Island was crucial but not, unfortunately, really pictorial' ${ }^{12}$

His paintings are very much part of a tradition of war art, and particularly naval war art, which stretches back at least to the $18^{\text {th }}$ century. It is undoubtedly this characteristic of his work, along with the very careful attention to detail, which has made him a popular artist among the armed services, and many of his canvases now hang in officers' messes and other places in military establishments. His work was certainly popular with Admiral of the Fleet Lord Lewin, who wrote in the introduction to The Making of a War Artist:

With meticulous research, drawing on his feel for the sea, experience of battle and the Falklands terrain and using his considerable artistic skill, David Cobb has depicted and described great events in such a way that those who were there will say 'That is exactly how it was'. All aspects are covered, sea, land and air, from hopeful departure for the unknown through hard-fought action and vital support to triumphal homecoming ... Those of us who were left 'abed in England' can be assured; this is how it must have been. ${ }^{13}$

51 Admiral Lewin presents the process of showing 'exactly how it was' as if it was unproblematic, but it clearly is not. Apart from anything else there is a curious contradiction in what he writes: either it 'was exactly' or it 'must have been' as David Cobb depicts it, but it cannot really be both. The second formulation suggests very 
clearly that a form of mental reconstruction was at work, and that would have to be rooted in probably unarticulated assumptions about what 'exactly how it was'.

So, as with the photographs published in the press, it would certainly appear that pictorial representation of the Falklands War was subjected to the pressures of consistency with a pre-existing 'style'. Many artists, and many photographers, were looking for something in the events of the war which they could then represent according to the established conventions of the genre.

In an article published in 2000, the photographer Gilles Saussier suggests that photographs taken by war reporters are like Russian dolls; they are presented as if they were a condensed version of the events themselves, a quintessence of historical meaning, and yet in a sense they do no more than simply revisit the clichés of previous wars, drawing heavily on a long tradition of Western art and iconography updated under the pretext of news:

Les photographies d'actualité sont pleines des cadavres ou des fantômes des images qui les ont précédées ... Les photographies de reportage sont des images-gigognes, images qui se donnent pour une condensation de l'événement lui-même, un concentré de signification historique, alors qu'elles sont des concentrés iconographiques, réalisés au prétexte de l'information. ${ }^{14}$

In a collection of essays entitled Framing the Falklands War, James Aulich writes similarly that the events of the war were narrated according to 'safely predictable narratives', ${ }^{15}$ and that 'the contemporary representation of the Task Force was situated firmly in mythological and historical time' so that the conflict could be 'in part, manufactured in signs rather than the specificities of history'. ${ }^{16}$

\section{Alternative visions}

There have been a number of pictures or collages made since the end of the conflict, not by 'war artists', official or otherwise, but by critics of the war and, perhaps even more importantly, by Falklands veterans trying to cope with the trauma they have experienced since their return and finding in art a way of expressing their feelings and emotions. Among the first of these two categories of artists there are a number of pictures suggesting that the war was an unnecessary one that served the interests of certain politicians. Raymond Briggs, better known for his cartoon books and films for children, used the medium of the children's book to produce a savage criticism of both Thatcher and Galtieri, suggesting that the end result of a quarrel between a tin-pot general and a hysterical Thatcher-figure was just a lot of broken people living on a land made largely uninhabitable by the debris of war. ${ }^{17}$ The cartoonist Ralph Steadman produced a cartoon, printed on the cover of the New Statesman, which similarly presented - or represented - the Falklands war as a thoroughly unsavoury affair. His cartoon shows two rotting stinking mutton chops, shaped in the form of a map of the two large islands of the Falklands archipelago, attacked by swarms of belligerent flies. ${ }^{18}$ Other paintings suggest there was a nasty form of jingoism over the conflict.

The art exhibited in Manchester in the late 1980s, mainly produced by veterans on post-traumatic stress therapy, mostly casts doubt on the motives behind the war, questioning whether the suffering it caused was in any way justified. It is mostly sad and often bitter. These alternative visions remained very much a minority, however, drowned out by those representations which reflected more conventional 
interpretations of the meaning of the conflict, closer to those expressed by Margaret Thatcher in the now-famous speech she gave at Cheltenham shortly after the conflict in which she suggested that the war had shown that the "nation still [had] those sterling qualities which shine through our history'. ${ }^{19}$

\section{Myths and heroes}

57 There is of course a long tradition of representing war in terms of the myth of individual heroism. In talking about myths, I want to be absolutely clear that I am referring to the way Roland Barthes used the term in Mythologies and Angus Calder applied it to the history of wartime Britain in The Myth of the Blitz. This emphatically does not mean that the events which may or may not have entered into mythology are untrue: I am not approaching this question in terms of a dialectic between 'myth and reality'. Calder finds it useful:

that many of us now understand 'myth' as a relevant term in discussion of apparent trivialities, like car design or magazine covers, obviously auratic phenomena like the charisma of film stars and politicians, and the projection of events such as the Falklands crisis. ${ }^{20}$

The Falklands war, like any other conflict, has its heroes. The best-known of these is Lt. Colonel Herbert Jones of the Parachute Regiment, who died during the battle of Goose Green. Almost universally referred to in the media as ' $\mathrm{H}$ ' Jones, he was shot while charging forward and attacking enemy positions at extreme risk to himself at a point in the battle when the momentum of the British advance seemed to be faltering. For this act of great bravery he was awarded the Victoria Cross.

There was a second soldier to win the VC in the Falklands, also posthumously. However his heroic action was given less coverage than that of 'H' Jones. Sergeant Ian John McKay, also of the Parachute regiment, died on the attack along Mount Longdon on the night of June 11/12, also losing his life in an attempt to ensure that the momentum of the battle was sustained at a crucial time. The reason why his name is much less wellknown has nothing to do with the extent of his bravery but everything to do with the time at which his actions took place and the consequent lower-key media focus on him: news of his bravery came in almost at the same time as news of the Argentine surrender and consequently his story was less conspicuous.

Both ' $\mathrm{H}$ ' Jones and Ian John McKay were killed while performing acts of gallantry which remind one of so many more acts of heroism for which men and women have been decorated in previous conflicts. The stories are very much of the kind celebrated in the 'war comics' which were once popular, so much so that many people have seen something of the spirit of the Boys' Own Paper in these courageous actions. This does not make them any the less real, and it does make the actions concerned any the less genuinely heroic. It does however emphasise that narratives of war have a certain momentum of their own.

61 Another man to have been recognised for his bravery is a Welsh Guard who was seriously injured during the attack on the Sir Galahad. Simon Weston was very badly burnt during the attack and had the courage to speak about his injuries in public, showing his dreadfully disfigured face on television as part of a campaign to collect funds for charity. For this quiet bravery he has won the admiration of the public and is 
a very popular figure. His is perhaps a rather different form of bravery and it has certainly touched the public's imagination.

of course there were many other brave men and women who played a number of very different roles during the campaign and after. The reason why I recall the way in which certain people have been so publicly identified is heroes is that narratives of war consistently highlight outstanding individuals: this process is an integral part of the representation of any conflict and seems necessary to bring the confused and largescale story of conflict into sharp focus.

\section{Conclusions}

63 Clearly representation involves much more than merely recalling 'events' for a reader, listener or viewer who was not actually there when the events involved occurred. Representation is very much about interpretation, about meaning, about making sense of things and about 'showing' things in a form which makes them 'real'. The meaning of the Falklands conflict was, and still is, an area of some controversy. Was it an opportunity for Britain to show to the world that she had not lost her spirit or was it an unnecessary conflict precipitated by a series of political blunders? Was it another 'fine hour' to be proud of and remembered or was it just the cause of needless pain for many of the participants? And was it an important moment when certain values were reasserted or was it simply a blip in history, something that does not really fit in with the big picture of $20^{\text {th }}$ century Britain? Was it just a curious throwback to the $19^{\text {th }}$ century or was it a defining moment in postwar British history? All of these conflicting or contrasting views have been expressed at one time or another over the last twenty or thirty years.

Answers to these questions will to a large extent pre-determine representations. Perhaps the unsettled nature of the debate explains why cinema seems largely to have ignored the Falklands. Perhaps the shortage of visual memories of the conflict means that there is no common pool of images to draw from to construct a narrative with which people could identify. Perhaps, too, the doubts about the real meaning of the conflict mean that it is not a subject which lends itself easily to any sort of historical reconstruction for mass audiences.

Beyond all of this there is the fact that the Falklands conflict was so rapidly superseded by other far more momentous events which have meant that debate about its significance became relatively pointless. Its meaning in the context of the Cold War, as an expression of Britain's will to respond to armed aggression and thus give substance to the crucial concept of deterrence, was soon deprived of much of its importance when the Soviet Union collapsed and the whole idea of deterrence changed completely. And while it is true that the meaning of the conflict has been contested, the debate is vastly less intense than that over more recent military engagements, especially in Iraq. Even the nature of warfare seems, though this may be more a question of appearance than reality, to have moved on so far and so quickly that the Falklands conflict appears to belong to a past which is of only limited relevance today. Representations of recent conflicts have emphasised the role of 'smart' weapons, missiles capable of striking identified targets with awe-inspiring accuracy. The war in the South Atlantic, by contrast, seems to belong to another world, with soldiers fighting with their bayonets and warships steaming into battle, both recalling representations of the Second, if not 
the First, World War. This is almost certainly an illusion but undoubtedly one which shaped representations.

Most images adopted artistic and photographic conventions based on the discourses or narratives of previous conflicts, though these expectations were frustrated when for example the official war artist failed to produce what some people would consider to be the 'right' sort of pictures. Those representational conventions were challenged by people who questioned the raison d'être of the conflict, especially those who suffered personally as a consequence. The Falklands War is therefore in many respects a case study of a conflict which shows just how much representation can be both ideological and contested.

\section{BIBLIOGRAPHY}

AULICH, James. Framing the Falklands War: Nationhood, Culture and Identity. London: Open

University Press, 1991.

CALDER, Angus. The Myth of the Blitz. London: Pimlico, 1991.

COBB, David. The Making of a War Artist. London: Conway, 1986.

FOSS, Brian. War Paint: Art, War and Identity in Britain 1939-1945. London: Yale, 2007.

Imperial War Museum. War: Oil Paintings in Public Ownership. London: The Public Catalogue Foundation, 2006.

KITSON, Linda. The Falklands War: A Visual Diary. London: Mitchell Beasley in association with the Imperial War Museum, 1982.

PARSONS, Michael. The Falklands War. Stroud: Sutton, 2000.

The Falklands Factor: Representations of a Conflict. Manchester: Manchester City Art Galleries, 1989.

\section{NOTES}

1. Cf. for example Michel FOUCAULT in L'archéologie du savoir, Paris : Gallimard, 1969 and L'ordre du discours, Paris : Flammarion, 1971.

2. On this subject see Lawrence FREEDMAN, 'The War and the Concept of Escalation', pp. 165-190, in Alex DANCHEV (ed), International Perspectives on the Falklands Conflict, Basingstoke : Macmillan, 1992, to which this analysis owes a considerable debt.

3. Admiral Lewin, in his biography, states that the time taken for the task force to reach the South Atlantic was principally dictated by purely military factors, though there may have been a two-day wait before the landing as the final response of the Argentine junta to Britain's peace proposals was awaited.

4. 'A Friend Indeed', leading article, The Times, May 11982.

5. Cf. House of Commons. First Report from the Defence Committee, session 1982-83, 'The Handling of Press and Public Information during the Falklands Conflict', vol I, Report and Minutes of 
Proceedings, 8 December 1982. London: HMSO, 1983, p. 63 ('Memorandum submitted by Independent Television News').

6. Quoted in Paul GOUGH, The Tyranny of Seeing, http://amd.uwe.ac.uk/index.asp?pageid=863.

7. Tom WILCOX in James AULICH, Framing the Falklands Conflict, op. cit., p. 63. The 'squiggles' reference comes from the Daily Star and the Daily Express, August 41982.

8. M. VAIZEY, Sunday Times, November 141982.

9. Linda KITSON, The Falklands War : A Visual Diary, London: Mitchell Beasley in association with the Imperial War Museum, 1982, p. 65.

10. David COBB, The Making of a War Artist, London: Conway, 1986, p. 26.

11. Ibid, p. 29.

12. Ibid, p. 35.

13. Ibid, p. 8.

14. Gilles SAUSSIER. 'Du reportage au jardinage' in Des territoires en revue, $3 / 5$, École Nationale des Beaux-Arts, avril 2000, p. 51.

15. James AULICH. Framing the Falklands War: Nation, Culture and Identity, London: Open University Press, 1991, p. 3.

16. Ibid, p. 10.

17. Raymond BRIGGS. The Tin-pot General and the Old Iron Woman, London: Hamish Hamilton, 1984.

18. Ralph STEADMAN, drawing for the cover of the New Statesman, May 141982.

19. Margaret THATCHER, speech to a Conservative party rally, Cheltenham racecourse, July 3 1982, http://www.margaretthatcher.org/speeches.

20. Angus CALDER, The Myth of the Blitz, London: Pimlico, 1991, p. 2

\section{ABSTRACTS}

The Falklands conflict was particularly remote and direct individual experience correspondingly rare. At the same time public interest in the conflict was intense. The events of the South Atlantic raise a number of important questions about the extent to which a distant confict can be 'represented'. Even at a very basic level of representation, it is clear that the facts cannot speak for themselves: without context bare facts can be misleading. In art and photography, it becomes obvious that representations are shaped according to pre-existing patterns. And like all previous conflicts, the Falklands War saw the projection of heroic narratives, recalling representations of previous conflicts.

Le conflit des Malouines s'est déroulé à l'autre bout du monde et peu de personnes pouvaient en avoir une expérience directe. Cependant le public témoigna d'un intérêt intense pour ces événements lointains, qui posent des questions fondamentales sur la possibilité même de représenter un conflit. Même au niveau le plus élémentaire de la repésentation, il est clair que les faits ne parlent pas d'eux-mêmes : sans le contexte, les faits bruts peuvent être trompeurs. Quant aux représentations artistiques et photographiques, il devient clair que les représentations sont élaborées en fonction de cadres pré-existants. Enfin, comme tous les conflits qui l'ont précédé, le conflit des Malouines a vu l'émergence de récits héroïques, là encore rappelant la façon dont les conflits antérieurs furent narrés. 
AUTHOR

MICHAEL PARSONS

Université de Pau et des Pays de l'Adour 